\title{
PENGARUH SUSUNAN LAMINA KAYU KARET TUA TERHADAP SIFAT KEKUATAN BALOK SILANG-I LAMINASI
}

\section{(The Effect of Arrangement of Old Rubber-Wood Laminae on Strength Properties of the Resulting Laminated I-Joist Beam)}

\author{
Oleh/By: \\ Han Roliadi ${ }^{1} \&$ Nurwati Hadjib ${ }^{1}$ \\ Pusat Litbang Hasil Hutan, Jl. Gunung Batu No. 5, Bogor \\ Telp. (0251) 8633378, Fax. (0251) 86333413.
}

Diterima 7 Desember 2009 disetujui 29 April 2010

\begin{abstract}
The assembling of I-joist laminated beam was carried out using old-rubber wood (Hevea brasiliensis M.A.) taken from rubber plantation regarded no longer productive for latex-exudate removal (about 25-30 years old). Initially, old rubber-wood logs (diameter about $10-25 \mathrm{~cm}$ ) were sawn into laminae. It revealed that the laminae yield $(36-39 \%)$ was lower than that commonly obtained from the sawing of large-diameter logs. The resulting laminae were reconstituted into Ijoist laminated beam using phenol-recorcinol-formaldebyde adhesive at room temperature.

Results of reconsitution (assembling) showed that strength properties of laminated I-joist beam with horizontalgluing profiles between laminae in the web portion (FSPL $=132.97 \mathrm{~kg} / \mathrm{cm}^{2}, M O R=184.13 \mathrm{~kg} / \mathrm{cm}^{2}, M O E=$ $54425.196 \mathrm{~kg} / \mathrm{cm}^{2}$, and $S h=2.9397 \mathrm{~kg} / \mathrm{cm}^{2}$ ) were lower than those of small-sized clear solid (defect-free) $\mathrm{kayu}$ manis wood, but bigher than those of I-joist with vertical-gluing profiles between laminae in the web as well as than those of the borizontally laminated beam made-up of old rubber-wood laminaes as well. Besides, the angle between wood ray and glue lines (planes) correlated negatively with the strengths of I-joist beam. This suggests the positive prospect of manufacturing laminated I-joist beam from old rubber-wood with vertical gluing patterns (in the web portion) between the laminae for construction, due to the saving-enbancement on raw-material usage.
\end{abstract}

Keywords: Old rubber-woods, rubberplantation's wastes, small diameter, low durability, laminated I-joist beam, strength properties

\begin{abstract}
ABSTRAK
Perakitan balok silang-I laminasi dilakukan menggunakan kayu karet tua (Hevea brasiliensis) asal pohon karet yang sudah tidak produktif lagi menghasilkan getah lateks (umur sekitar 25-30 tahun). Mula-mula, dolok kayu karet (diameter sekitar 10-25 cm) terlebih dulu dibentuk menjadi lamian (bilahbilah) melalui penggergajian. Rendemen bilah tersebut (36-39\%) masih lebih rendah dari pada rendemen yang umum dari kayu berdiameter besar. Bilah yang dihasilkan dirakit menjadi balok silang-I menggunakan perekat fenol-resorsinol-formaldehida pada suhu kamar.

Hasil perakitan menunjukkan kekuatan balok silang-I laminasi dengan profil rekatan horisontal antar lamina dibagian tubuh atau badan (keteguhan lengkung pada batas proporsi $=132.97 \mathrm{~kg} / \mathrm{cm}^{2}$, MOR $=184.13 \mathrm{~kg} / \mathrm{cm}^{2}$, MOE $=54425.196 \mathrm{~kg} / \mathrm{cm}^{2}$, dan keteguhan geser horisontal $=2.9397 \mathrm{~kg} / \mathrm{cm}^{2}$ ) lebih rendah dari pada sifat balok kayu karet utuh berdimensi kecil bebas cacat, tetapi lebih tinggi dari
\end{abstract}


pada balok silang-I laminasi dengan profil rekatan vertikal dan produk balok laminasi (glulam) juga dari kayu karet tua dengan profil rekatan horisontal antar lamina. Di samping itu terdapat korelasi nyata negatif antara sudut jari-jari kayu - bidang rekatan dengan sifat mekanis/ kekuatan balok silang-I laminasi. Ini mengindikasikan prospek positif pembuatan balok silang-I laminasi laminasi dari kayu karet tua dengan profil rekatan vertikal tersebut untuk tujuan konstruksi, karena dapat lebih menghemat pemakaian bahan baku.

Kata kunci: Kayu karet tua, limbah perkebunan karet, diameter kecil, keawetan rendah, balok silang-I laminasi, sifat kekuatan

\section{PENDAHULUAN}

Indonesia telah mengekstrak dolok kayu dari hutan alam tropisnya yang umumnya berdiameter besar secara intensif sejak awal tahun 1970 guna memasok kebutuhan bahan baku industri pengolahan kayu dan usaha perkayuan lain. Dewasa ini penyediaan kayu hutan alam dari tahun ke tahun semakin terbatas dan langka. Hal tersebut terjadi selain akibat adanya pembalakan liar (illegal logging) juga karena kesalahan manajemen di masa lampau, sehingga di masa mendatang sulit bagi Indonesia untuk mendapatkan dolok-dolok berdiameter besar (Anonim, 2002, 2003, 2005, dan 2006). Akibatnya, bahan baku kayu alternatif diperlukan guna memasok keperluan industri kayu dan usaha perkayuan, di antara alternatif tersebut adalah kayu karet tua sebagai limbah perkebunan karet yang sudah tidak produktif lagi.

Potensi kayu karet tua cukup besar dengan lahan perkebunan karet di Indonesia seluas 3,4 juta ha diperkirakan mampu memyediakan kayu karet sebesar 31,4 juta $\mathrm{m}^{3}$ /tahun (Nurhayati et al., 2006). Kelemahan kayu karet adalah berkeawetan rendah (kelas awet V) dan mudah diserang jamur biru (blue stain). Selanjutnya, kayu karet mudah dikeringkan akan tetapi mudah berubah bentuk (Martono, 2006). Kelemahan kayu karet tersebut perlu diusahakan solusinya terkait dengan usaha pemanfaatannya sebagai kayu alternatif. Selanjutnya karena pohon kayu karet sengaja ditanam sebagai usaha perkebunan, maka umumnya berkualitas lebih rendah dari pada kayu hutan alam, yaitu antara lain pohon karet tersebut berdiameter kecil, berporsi kayu muda (juvenile wood) besar, dan mungkin terdapat cacat seperti kayu reaksi, mata kayu, dan kulit tersisip (Silva, 1970; Oey, 1990). Kelemahan kayu karet tersebut perlu diusahakan solusinya terkait dengan usaha pemanfaatannya sebagai kayu alternatif.

Dalam usaha pemanfaatan kayu karet tua menjadi produk bernilai tambah, diantara bentuk produk yang disarankan diantaranya adalah balok silang-I laminasi. Balok tersebut merupakan salah satu macam produk komposit kayu, di mana melalui pandangan melintang terlihat sebagai bentuk "I" (Gambar 1). Bagian atas dan bawah produk laminasi tersebut diberi istilah sayap, sedangkan bagian tengah yang tegak disebut porsi tubuh tubuh (Hunt dan Winandy, 2003; Leichti, 1986). Di samping itu, saran pembuatan balok silang-I laminasi dari kayu berdiameter kecil dan kayu reaksi juga dianggap sebagai usaha diversifikasi produk komposit kayu (Hunt, 2000; Youngs dan Hammet, 2001; Hunt dan Winandy, 2003).

Manfaat pembuatan balok silang-I laminasi laminasi adalah (Anonim, 1956 dan 1999; Maloney, 1986; Freas dan Selbo, 1954; McGavin, et al., 2006; Selbo, 1975) antara lain: 1) Sifat dan ukuran (dimensi) balok silang-I laminasi dapat direkayasa sesuai dengan tujuan 
penggunaannya; 2) Pengolahan/pembuatan balok silang-I laminasi dapat menggunakan bahan baku secara efisien; 3) Meminimumkan keretakan kayu, dan mengurangi pengaruh kayu muda dan cacat-cacat lain (mata kayu, kayu reaksi, kulit tersisip, dan sebagainya); 4) Proses laminasi menghasilkan produk (balok silang-I laminasi) dengan bentuk lebih lurus, dimensi lebih stabil, dan lebih konsisten sehingga bermanfaat sebagai bahan konstruksi; 5) Dapat menggunakan kayu berkualitas rendah dan/atau bernilai ekonomi rendah; 6) Mengurangi penetrasi dan penguapan air pada permukaan kayu yang dapat mengakibatkan perubahan bentuk produk komposit tersebut (balok silang-I laminasi); 7) Meningkatkan keawetan dan ketahanan terhadap api, karena adanya lapisan bahan perekat yang dapat merupakan barrier, dan bentuk komposit yang relatif besar sehingga menghambat serangan organisme perusak kayu dan juga memperlambat pergerakan nyala api mulai dari bagian permukaan produk komposit hingga bagian dalamnya; 8) Memungkinkan poduksi bahan komposit dengan biaya rendah dan jangka waktu pengembalian modal singkat; dan (9) Ikut menunjang usaha pelestarian hutan dan kelangsungan bahan baku industri perkayuan. Terkait dengan segala tersebut dan dalam upaya mengoptimalkan pemanfaatan kayu karet, telah dilakukan penelitian pemanfaatannya menjadi balok silang-I laminasi.

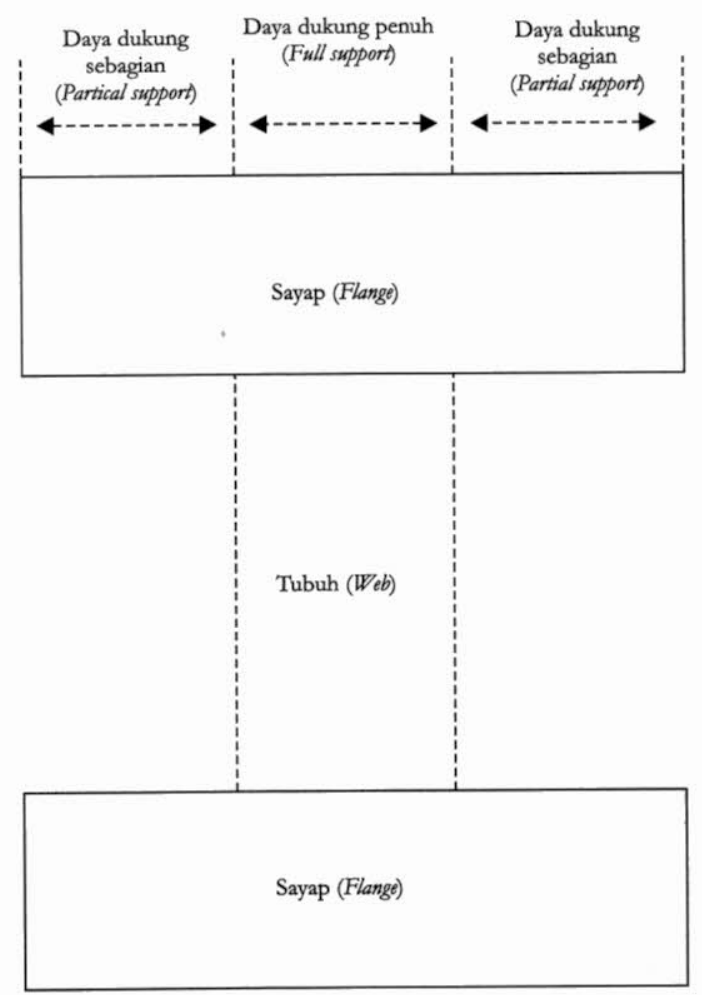

Gambar 1. Penampang melintang balok silang-I laminasi Figure 1. Cross-section views of laminated I-joist beam 


\section{BAHAN DAN METODE}

\section{A. Bahan dan Alat}

Sebagai bahan penelitian adalah kayu karet (Hevea brasiliensis M.A.) yang sudah berumur tua berdiameter kecil $(\varnothing 10-25 \mathrm{~cm})$ diambil dari perkebunan tanaman karet yang sudah tidak produktif menghasilkan getah lateks (umur sekitar 30-40 tahun) berlokasi di daerah Sarni Sindang (Jawa Barat), milik PT Perkebunan Negara VIII. Sebagai bahan penunjang adalah bilah gergaji, klem, kantung plastik, dan ampelas.

Selanjutnya, peralatan yang digunakan adalah gergaji, torsimeter, mixer dan alat kempa dingin untuk perakitan balok silang-I laminasi laminasi. Sedangkan pengujian sifat balok silang-I laminasi mencakup peralatan mesin pemilah kayu (Panter), timbangan, deflektometer, oven, dan universal testing machine (U'TM).

\section{B. Prosedur Kerja}

Prosedur pembuatan balok silang-I laminasi mulai dari tahapan pelaksanaan hingga pengujian diuraikan berikut ini :

1. Dolok kayu dari jenis kayu karet tua dikumpulkan dalam jumlah cukup dari areal perkebunan karet tidak produktif.

2. Dolok tersebut mula-mula ditentukan volumenya (V1) di mana hasilnya sekitar 0.046$0.098 \mathrm{~m}^{3}$ untuk setiap dolok, lalu dibelah-belah menjadi papan dengan tebal nominal sekitar 2 $\mathrm{cm}$ menggunakan mesin penggergajian. Papan yang dihasilkan diukur dimensinya, kemudian ditentukan volume masing-masing papan dan volume total keseluruhan papan tersebut (V2). Selanjutnya, ditentukan rendemen penggergajian (R) dengan rumus:

$\mathrm{R}=(\mathrm{V} 2 / \mathrm{V} 1) \times 100 \%$

3. Papan hasil penggergajian kemudian dikeringkan dengan bagan pengeringan yang sesuai hingga mencapai kadar air kering udara (sekitar 12-14\%).

4. Papan yang telah dikeringkan lalu dipotong-potong dan diserut menjadi bilah (papan lamina) sedemikian rupa sehingga diperoleh ukuran/dimensi sesuai dengan yang dikehendaki (tebal $2 \mathrm{~cm}$; panjang $2 \mathrm{~m}$; dan lebar $4 \mathrm{~cm}, 6 \mathrm{~cm}$, dan $8 \mathrm{~cm}$ ).

5. Terhadap papan lamina dilakukan pengujian berat jenis, dan sifat kelenturan/modulus elastisitas (MOE) dengan cara tidak merusak (non destruktif) menggunakan mesin pemilah kayu Panter. Cara tidak merusak tersebut adalah dengan hanya melengkungkan papan lamina tersebut hingga tidak melewati batas proporsi. Selanjutnya, pada pelengkungan tersebut dicatat defleksi dan bebannya guna penentuan MOE yang mengacu pada standar ASTM D3737 (Anonim, 1984). Dari hasil pengujian tersebut, dilakukan sortasi terhadap papanpapan lamina dan selanjutnya dibuat menjadi 3 kelompok berdasarkan nilai MOE yaitu rendah, sedang dan tinggi.

6. Selesai pemilahan, papan lamina siap dirakit dan direkat menjadi balok silang-I laminasi. Perekatan dilakukan pada bidang permukaan masing-masing papan tersebut, dan bahan perekat yang digunakan adalah fenol-resorsinol-formaldehide dengan komposisi campuran (berdasarkan berat) masing-masing berturut-turut 1,25:1,25:0,33 (Blomquist et al., 1981) dengan berat laburan 170 gram $/ 100 \mathrm{~cm}^{2}$. Proses perekatan dilakukan dengan kempa dingin 
(suhu kamar) pada tekanan $10 \mathrm{~kg} / \mathrm{cm}^{2}$ selama 2 jam. Untuk perekatan menjadi balok silang-I laminasi, bagian sayap (atas dan bawah) menggunakan papan lamina dengan nilai MOE tinggi dan sedang (Gambar 2a dan 2b), sedangkan untuk bagian tubuh digunakan papan lamina dengan MOE rendah. Balok silang-I laminasi yang dibentuk terdiri dari 2 macam konfigurasi yaitu bilah di bagian tubuh direkat dalam susunan horisontal dan vertikal, sedangkan pada sayap tetap horisontal (Gambar 2a dan 2b).

7. Selanjutnya dilakukan pengkondisian terhadap balok Silang-I laminasi selama 1 minggu.

8. Setelah pengkondisian, dilakukan pengujian sifat kekuatan balok silang-I laminasi dengan cara merusak (destruktif) melalui pelengkungan (bending) menggunakan alat UTM. Pengujian tersebut mencakup momen inersia, lokasi titik berat (center of gravity) dan bidang netral (neutral plane), keteguhan patah (MOR), keteguhan lentur / modulus elastisitas (MOE), dan keteguhan geser horisontal maksium (maximum horizontal shear), keteguhan lengkung pada batas proporsi (fiber stress at proporsional limit), juga mengacu pada standar ASTM D 3737 (Anonim, 1984).

9. Untuk pembanding sifat balok silang-I laminasi yang diuji tersebut, juga dibuat berturutturut balok kayu karet laminasi/glulam (Gambar 3a) dan balok kayu karet utuh bebas cacat (Gambar 3b). Balok kayu karet utuh berukuran 2,5 $\mathrm{cm}$ x 2,5 $\mathrm{cm}$ x 0,80 cm. Sedangkan balok kayu laminasi berukuran panjang $2 \mathrm{~m}$, lebar $8 \mathrm{~cm}$, dan tinggi $14 \mathrm{~cm}$ terdiri dari 7 bilah (papan lamina) yang disusun dan direkat secara horisontal masing-masing dengan ukuran tebal $2 \mathrm{~cm}$. Pada perakitan balok kayu laminasi tersebut (Gambar 3a), lamina terluar dan lamina berikutnya pada balok tersebut (bagian atas dan bawah) disusun dari lamina dengan MOE tinggi dan rendah, sedangkan lamina bagian tengah balok menggunakan lamina dengan MOE rendah.

10. Di samping itu, terhadap balok silang-I laminasi (Gambar 2a dan 2b), dan balok kayu laminasi (Gambar 3a), dilakukan pengukuran sudut antara jari-jari kayu dengan lapisan rekatan (glueline) antar lamina, guna mencermati kemungkinan adanya korelasi dengan kekuatan balok tersebut.

\section{Rancangan Percobaan dan Analisis Data}

Data hasil pengujian sifat kekuatan balok silang-I laminasi ditelaah dengan rancangan acak lengkap satu faktor dengan ulangan sebanyak 2-5 kali. Sebagai faktor/perlakuan (T) adalah balok silang-I laminasi dengan bilah pada bagian tubuh saling direkat secara horisontal (t1) dan secara vertikal (t2); balok kayu laminasi (t3); dan balok kayu utuh bebas cacat (t4) dari jenis kayu yang sama sebagai pembanding sifat balok silang-I laminasi hasil percobaan. Profil atau konfigurasi dengan kode-kode $\mathrm{t} 1, \mathrm{t} 2, \mathrm{t} 3$, dan $\mathrm{t} 4$ tersebut dapat dilihat berturut-turut pada Gambar-gambar 2a, 2b, 3a, dan 3b. Juga ikut disertakan karakeristik kayu yang mungkin berpengaruh pada sifat balok silang-I laminasi antara lain sudut antara jari-jari kayu dengan bidang (lapisan) rekatan (glueline) (X1) dan berat jenis papan lamina (X2) yang saling direkatkan. 


\section{HASIL DAN PEMBAHASAN}

\section{A. Rendemen Penggergajian, Berat Jenis, dan Kadar Air Kayu Karet Tua}

Rendemen kayu gergajian dolok kayu karet tua berkisar 36-39\%, di mana lebih rendah dari pada rendemen yang diperoleh secara umum dari penggergajian dolok kayu yaitu $50-55 \%$ (Rachman, 1999). Hal tersebut karena diameter kayu karet tua relatif kecil (di bawah $25 \mathrm{~cm}$ ) dan juga adanya cacat kayu berupa kayu reaksi, mata kayu, dan kulit tersisip.

Berat jenis kayu karet tua (dasar kering udara) berkisar 0.48-0.56, di mana termasuk kategori sedang (di bawah 0.80) (Oey, 1990; Martawijaya et al., 2005). Berat jenis berpengaruh positif terhadap sifat kekuatan kayu termasuk juga produk turunannya (Haygreen and Bowyer, 1989). Kadar air kayu karet tua juga menunjukkan variasi (12.62-13.67\%). Kadar air tersebut terletak pada selang kadar air kering udara secara umum yaitu 12-14\% (Anonim, 1995; Martawijaya et al., 2005).
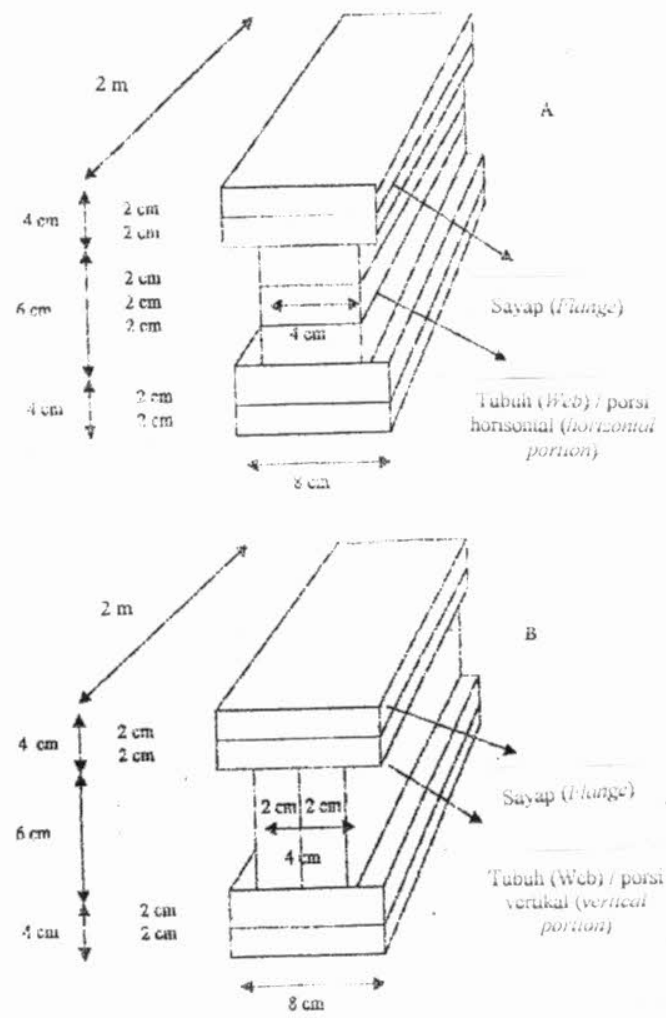

Gambar 2. Profil balok silang-I laminasi yang dibuat dengan bilah pada bagian tubuh saling direkat secara horisontal (A), dan secara vertikal (B) (tipe A dan B masing-masing dibuat dari lamina jenis kayu karet)

Figure 2. Profiles of I-joist beam assembled with the laminae on the web, glued together borizontally (A), and vertically (B) (Both types $A$ and $B$ used laminae from rubber-wood species) 


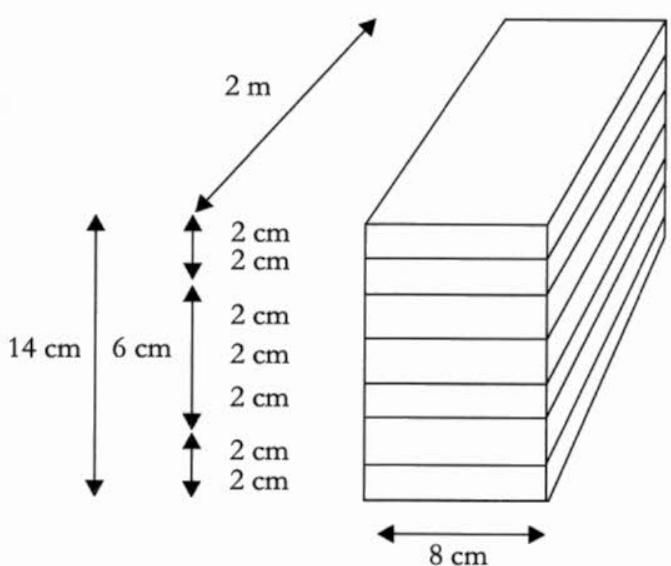

A

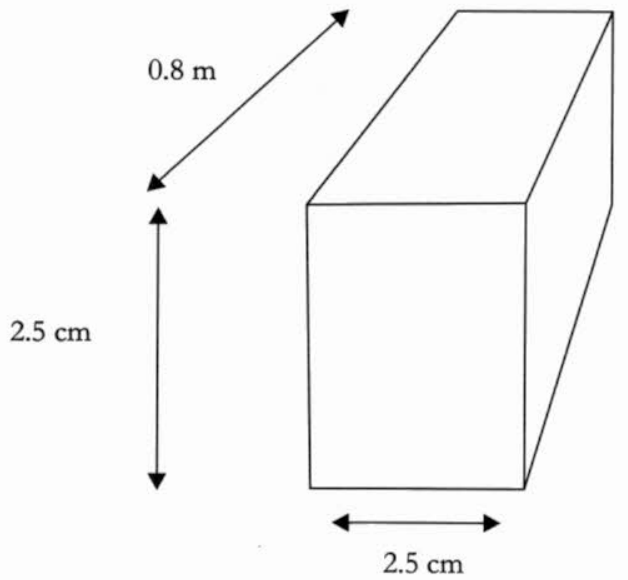

B

Gambar 3. Profil balok kayu lamina (A), dan balok kayu utuh bebas cacat (B) untuk pembanding sifat-sifat balok silang-I laminasi (tipe A dan B masingmasing menggunakan juga kayu karet)

Figure 3. Profiles of laminated wood beam (A), and defect-free solid wood) (B) as the comparison for I-joist beam (Both types $A$ and B used rubber wood as well)

\section{B. Sifat Fisis dan Kekuatan Balok Silang-I Laminasi}

Data hasil pengujian balok silang-I laminasi dengan profil rekatan horisontal dan vertikal di bagian tubuh, berikut pembandingnya (Gambar 2a, 2b, 3a, 3b) disajikan pada Tabel 1. Pusat berat (center of gravity) balok silang-I laminasi dan balok laminasi menunjukan variasi yaitu 6.12-6.71 cm pada jarak vertikal ke atas dari bagian dasar balok tersebut (Tabel 1). Variasi tersebut diakibatkan oleh profil dan ukuran balok-joist berikut pembandingnya ( $\mathrm{t} 1, \mathrm{t} 2$, t3, t4; berturut-turut pada Gambar 2a, 2b, 3a, dan 3b) yang tidak sama satu terhadap lainnya (Brown, et al., 1952). Demikian pula momen inersia bervariasi $\left(1298.792-2360.652 \mathrm{~cm}^{4}\right)$. 
Variasi momen tersebut juga diakibatkan oleh perbedaan profil balok silang I-laminasi yang berbentuk huruf I dilihat dari penampang melintang (Gambar 2a dan 2b) dan profil pembandingnya yang berbentuk empat persegi panjang (Gambar 3a). Sebaliknya untuk profil yang sama, variasi moment inersia diakibatkan oleh ukurannya yang tidak sama betul satu terhadap lainnya (Beer dan Johnston, 1987).

Tabel1. Sifat fisik and kekuatan balok silang-I laminasi dari kayu karet tua*) Table 1. Physical and strength properties of laminated I-joist beam assembled from old rubber-wood $*$ )

\begin{tabular}{|c|c|c|c|l|l|l|l|l|}
\hline $\begin{array}{c}\text { Profil } \\
\text { (Profile) } \\
(\mathrm{T})\end{array}$ & \multicolumn{2}{|c|}{$\begin{array}{c}\text { Kayu } \\
\text { (Wood })\end{array}$} & \multicolumn{8}{c|}{ Sifat (Properties) } \\
\cline { 2 - 8 } & $\mathrm{A}$ & BJ & $\begin{array}{l}\text { TP } \\
(\mathrm{cm})\end{array}$ & $\begin{array}{l}\text { FSPL } \\
\left(\mathrm{kg} / \mathrm{cm}^{2}\right)\end{array}$ & $\begin{array}{l}\text { MOR } \\
\left(\mathrm{kg} / \mathrm{cm}^{2}\right)\end{array}$ & $\begin{array}{l}\text { MOE } \\
\left(\mathrm{kg} / \mathrm{cm}^{2}\right)\end{array}$ & $\begin{array}{l}\text { Sh } \\
\left(\mathrm{kg} / \mathrm{cm}^{2}\right)\end{array}$ & $\begin{array}{l}\mathrm{I} \\
\left(\mathrm{cm}^{4}\right)\end{array}$ \\
\hline \multicolumn{8}{|c|}{ Balok silang-I laminasi (I-joist beam $)$} \\
\hline $\mathrm{t} 1$ & 44 & 0.53 & 6.28 & 161.5247 & 220.531 & 62507.59 & 3.0626 & 1298.792 \\
\hline $\mathrm{t} 2$ & 44 & 0.52 & 6.71 & 52.0339 & 118.7929 & 52518.13 & 1.4093 & 1320.947 \\
\hline \multicolumn{8}{|c|}{ Pembanding (Comparison) } \\
\hline $\mathrm{t} 3$ & 46.3 & 0.48 & 6.12 & 41.7473 & 60.5427 & 13650.83 & 1.6264 & 2360.652 \\
\hline $\mathrm{t} 4$ & - & 0.51 & 1.25 & 345.5774 & 461.8192 & 50631.64 & 12.1918 & 864.000 \\
\hline
\end{tabular}

Keterangan (Remarks): Untuk notasi (for the notations off) $\mathrm{T}, \mathrm{t} 1, \mathrm{t} 2, \mathrm{t} 3, \mathrm{t} 4$, lihat aspek Bahan dan Metode (please refer to the aspects of Materials and Methods) *) Rata-rata dari 2-5 ulangan/Average of 2-5 replications; $\mathrm{A}=$ sudut jari-jari kayu terhadap bidang (lapisan) rekatan / Angle between wood ray and glueline; TP = titik pusat berat/Center of gravity (jarak dari bagian dasar balok silang-I laminasi/with the distance from the base of I-joist beam); BJ = berat jenis kayu lamina/Laminae-wood specifiv gravity (kering udara / air dry); FSPL = keteguhan lengkung pada batas proporsi/bending strength at proportional limit, MOR = keteguhan lengkung pada keadaan patah/bending strength at failure; MOE = keteguhan elastis (lentur) melalui pelengkungan/ Modulus of elasticity in bending, $\mathrm{Sh}=$ keteguhan geser horisontal maksimum/ Maximum horizontal shear strength; I = momen inersia / moment of inertia

Analisis keragaman terhadap keteguhan lengkung pada batas proporsi (FSPL) dan keteguhan lentur (MOR), menunjukan bahwa sudut antara jari-jari kayu dengan bidang (lapisan) rekatan berpengaruh nyata secara negatif (Tabel 2); sedangkan terhadap keteguhan lengkung pada batas patah (MOR) tidak nyata. Pengaruh nyata tersebut dapat dimengerti karena semakin kecil sudut tersebut, semakin besar luas bidang persentuhan antara bagian (penampang) melintang jari-jari kayu dengan permukaan lamina kayu sehingga memungkinkan lebih banyak bahan perekat yang memasuki struktur lamina melalui jari-jari dan dengan demikian memperkuat daya cengkeram perekat terhadap lamina kayu (substrate) pada saat perekat tersebut mengeras (curing/set) (Blomquist et al., 1981). Sebagai akibatnya sifat kekuatan balok silang-I laminasi (FSPL dan MOE) meningkat pula.

Lebih lanjut, analisa keragaman menunjukkan bahwa berat jenis berpengaruh nyata secara positif (Tabel 2) terhadap keseluruhan sifat kekuatan (FSPL, MOR, MOE, dan Sh). Hal ini dapat dijelaskan pula karena sebagaimana diuraikan sebelumnya berat jenis 
berpengaruh positif terhadap sifat kekuatan (Haygreem dan Bowyer, 1989). Analisa keragaman menunjukkan pula bahwa perbedaan profil balok silang-I laminasi ( $\mathrm{t} 1 \mathrm{~d}$ an $\mathrm{t} 2$ ) berikut pembandingnya ( $\mathrm{t} 3$ dan $\mathrm{t} 4$ ) berpengaruh nyata terhadap sifat kekuatan balok-I-joist dan pembandingnya (Tabel 2). Penelaahan dengan uji BNJ mengenai pengaruh profil tersebut dapat dilihat (Tabel 3) dengan melakukan adjustment sudut bidang rekatan (X1 = $\left.44.77^{\circ}\right)$ dan berat jenis kayu lamina $(\mathrm{X} 2=0.51)$. Terlihat bahwa secara keseluruhan sifat kekuatan balok silang-I laminasi dengan profil lamina direkat secara horisontal pada bagian web/tubuh (Gambar 2a) lebih tinggi dari pada sifat dengan profil lamina yang direkat secara vertikal di bagian tubuh tersebut (Gambar $2 \mathrm{~b}$ ) dengan total skor (hasil manipulasi uji BNJ) berturut-turut 13 dan 9 (Tabel 3). Pada uji kekuatan balok silang-I laminasi dengan posisi

Tabel2. Analisis keragaman terhadap sifat mekanis/kekuatan balok silang I-lami dari kayu karet tua

Table 2. Analysis of variances on mechanical/strength properties of I-joist beam from old rubber-wood

\begin{tabular}{|c|c|c|c|c|c|c|c|c|c|}
\hline \multirow{3}{*}{$\begin{array}{c}\text { Sumber } \\
\text { keragaman } \\
\text { (Sources } \\
\text { of variation) }\end{array}$} & \multirow{3}{*}{$\begin{array}{l}\mathrm{db} \\
(d f)\end{array}$} & \multicolumn{8}{|c|}{ Sifat (Properties) } \\
\hline & & \multicolumn{2}{|c|}{ FSPL } & \multicolumn{2}{|c|}{ MOR } & \multicolumn{2}{|c|}{$\mathrm{MOE}$} & \multicolumn{2}{|c|}{ Sh } \\
\hline & & ? & $\begin{array}{c}\text { F- } \\
\text { hitung } \\
(F-\text {-calc. })\end{array}$ & $?$ & $\begin{array}{c}\text { F- } \\
\text { hitung } \\
\text { (F-calc.) }\end{array}$ & $?$ & $\begin{array}{c}\text { F- } \\
\text { hitung } \\
\text { (F-calc. })\end{array}$ & $?$ & $\begin{array}{c}\text { F- } \\
\text { hitung } \\
\text { (F-calc.) }\end{array}$ \\
\hline $\begin{array}{l}\text { Profil balok } \\
\text { silang-I laminasi/ } \\
\text { Profiles of Ljoist } \\
\text { beam (T) }\end{array}$ & 3 & - & $63.34 * *$ & - & $126.95^{* *}$ & - & $3.74^{*}$ & - & $\begin{array}{c}695.25^{*} \\
*\end{array}$ \\
\hline $\begin{array}{l}\text { Sudut antara jari- } \\
\text { jari kayu dengan } \\
\text { bidang (lapisan } \\
\text { rekatan) / Angle of } \\
\text { wood ray - glueline, } \\
\text { X1 }\end{array}$ & 1 & -3.99 & $11.13^{* *}$ & -6.29 & $1.47 \mathrm{tn}$ & -0.0196 & $9.52^{* * *}$ & -0.0298 & 0.12 tn \\
\hline $\begin{array}{l}\text { Berat jenis kayu / } \\
\text { Wood specific } \\
\text { gravity, X2 } \\
\text { Sisa / Resduals }\end{array}$ & 1 & 967.41 & $39.13 * *$ & 1591.97 & 7.63* & 5.2553 & $1.56 \mathrm{tn}$ & 7.2032 & $0.50 \mathrm{tn}$ \\
\hline Rata-rata / Means & - & \multicolumn{2}{|c|}{150.2208} & \multicolumn{2}{|c|}{215.4214} & \multicolumn{2}{|c|}{4.5702} & & \\
\hline $\begin{array}{l}\text { Satuan /Units } \\
\text { Koefisien korelasi } \\
\text { / Correalation coeff. } \\
\text { (R), \% }\end{array}$ & - & \multicolumn{2}{|c|}{$\begin{array}{l}\mathrm{kg} / \mathrm{cm}^{2} \\
0.6759^{* * *}\end{array}$} & \multicolumn{2}{|c|}{$\begin{array}{l}\mathrm{kg} / \mathrm{cm}^{2} \\
0.8142^{* *}\end{array}$} & \multicolumn{2}{|c|}{$\begin{array}{c}\log \left(\mathrm{kg} / \mathrm{cm}^{2}\right) \\
0.8627^{*}\end{array}$} & \multicolumn{2}{|c|}{$\begin{array}{l}\mathrm{kg} / \mathrm{cm}^{2} \\
0.4891^{*}\end{array}$} \\
\hline $\begin{array}{l}\text { Koefisien } \\
\text { keragaman / } \\
\text { Coeff. of variation } \\
(\%) \\
\text { D0.053) }\end{array}$ & - & \multicolumn{2}{|c|}{8.2449} & \multicolumn{2}{|c|}{16.3201} & \multicolumn{2}{|c|}{3.4455} & \multicolumn{2}{|c|}{10.2839} \\
\hline
\end{tabular}

Keterangan (Remarks): $\beta=$ koefisien regeresi/Regr. coefficient ${ }^{*}=$ nyata pada taraf $/$ significant at $5 \% ; * *=$ nyata pada taraf $/$ significant at $1 \% ;$ tn $=$ tak nyata $/$ not significant, $\mathrm{P}=$ peluang (probability); D0.05 = Nilai kritis uji jarak beda nyata jujur (BNJ) pada / critical value of honestly significant difference at (HSD) $5 \%$; untuk notasi (for the notations of) FSPL, MOR, MOE, Sh lihat Tabel 1 (refer to Table 1); untuk (for) MOE, dalam bentuk transformasi log (in log transformation) 


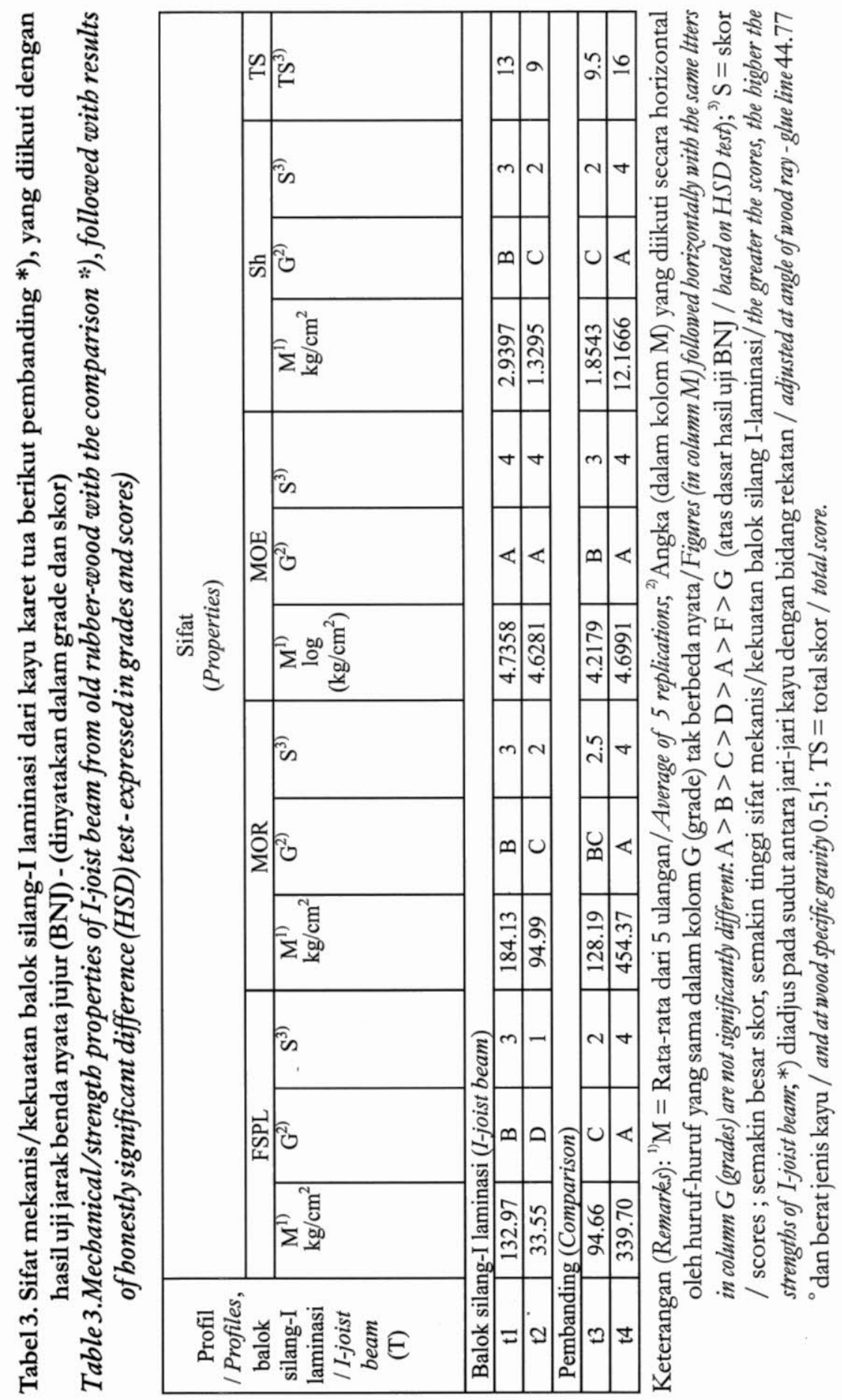




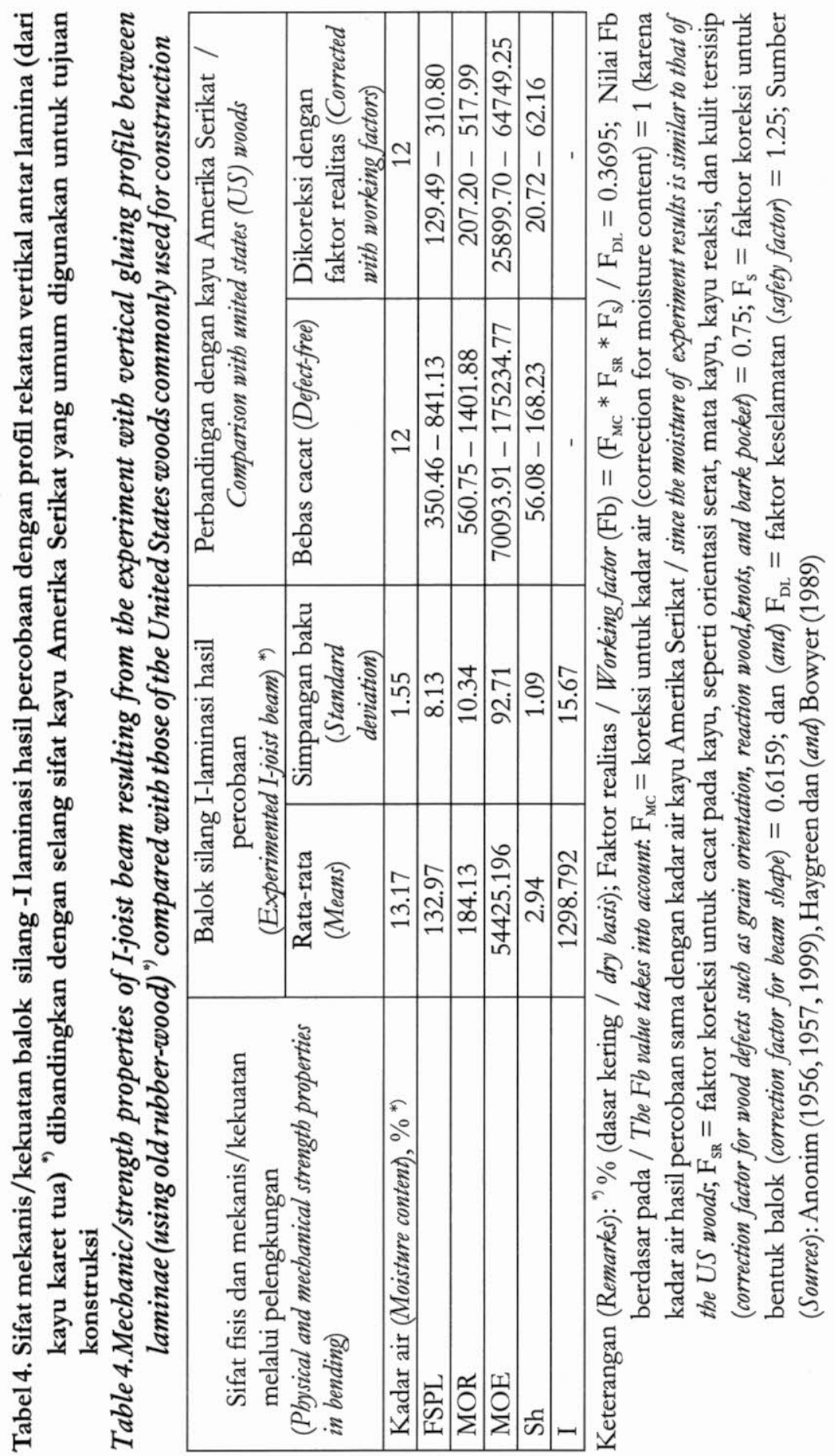


rekatan horisontal antara lamina di bagian tebuh melalui pelengkungan, keteguhan rekatan (gaya adesi) antara lamina-perekat-lamina dengan posisi rekatan horisontal tersebut (Gambar 3a) nampaknya lebih banyak berperan. Sebaliknya pada uji terhadap balok silang-I laminasi dengan posisi rekatan vertikal antar lamina di bagian web (Gambar 3b), sifat kekuatan internal lamina (kohesi) lebih banyak berperan dari pada keterguhan rekat vertikal tersebut. Ini mengindikasikan bahwa untuk balok silang-I laminasi dari kayu karet tua, keteguhan rekat (adesi) antara lamina-perekat-lamina yang disusun dan direkat secara horisontal pada bagian web balok tersebut (Gambar 3a) lebih berperan dari pada keteguhan internal atau kohesi dalam struktur lamina yang tersusun secara vertikal (Gambar 3b) dalam mempengaruhi sifat kekuatan balok silang-I laminasi.

Berdasarkan hasil uji jarak beda nyata jujur (BNJ), ternyata secara keseluruhan sifat kekuatan balok silang-I laminasi dengan posisi rekatan horisontal ataupun vertikal antar lamina dibagian web (Gambar 3a, 3b, 4b, dan Tabel 3) lebih rendah dari pada sifat bahan pembanding yaitu kayu utuh kayu karet tua sendiri (Gambar 4b) dengan total skor berturutturut 13, 9, dan 16. Akan tetapi, sifat kekuatan balok laminasi (glulam) kayu karet tua lebih rendah dari pada sifat balok silang-I laminasi dengan profil rekatan horisontal antar lamina di bagian web, dengan skor berturut-turut 9.5 dan 13 (Gambar 3a, 3b, 4a, dan Tabel 3). Diduga ini ada peranannya dengan lamina bagian web balok silang-I laminasi yang ukuran lebarnya lebih kecil dari pada lebar lamina untuk glulam. Lebih kecilnya lebar lamina tersebut mengurangi pula terbawanya bagian cacat kayu (kayu reaksi, mata kayu, kulit tersisip, dan sebagainya yang dapat menurunkan sifat kekuatan kayu) pada lamina untuk perakitan balok silang-I laminasi. Lebih lanjut, sifat fisis dan kekuatan balok silang-I laminasi dengan profil rekatan horisontal antar lamina, yang memiliki skor 13 (Gambar 3a dan Tabel 3) ternyata masih sebanding dengan dibandingkan dengan selang sifat kayu di Amerika Serikat yang umum digunakan untuk tujuan konstruksi setelah dikoreksi dengan faktor realitas (Tabel 4). Ini mengindikasikan pula bahwa pembuatan balok silang-I laminasi dari kayu karet tua khususnya dengan profil rekatan antar lamina horisontal (Gambar 2b) pada bagian web lebih berprospek dari pada pembuatan produk balok laminasi menggunakan jenis kayu yang sama (Gambar 3a), karena lebih menghemat pemakaian bahan baku kayu.19

\section{KESIMPULAN DAN SARAN}

\section{A. Rendemen Penggergajian dan Berat Jenis Kayu Karet Tua}

Rendemen penggergajian kayu karet tua menunjukan variasi (36-39\%) di mana juga lebih rendah dari pada rendemen umum untuk kayu berdiameter besar. Berat jenis bervariasi pula (0.48-.0.56) yang juga termasuk kelompok kayu dengan berat jenis sedang.

\section{B. Sifat Kekuatan Balok Silang-I Laminasi}

Sifat kekuatan balok silang-I laminasi dari dengan kayu karet tua dipengaruhi secara negatif oleh sudut jari-jari kayu dengan bidang rekatan (mengunakan bahan perekat fenolresorsinol-formaldehida) dan secara positif oleh berat jenis.

Sifat kekuatan balok silang-I laminasi dari kayu karet tua dengan profil rekatan horisontal antar lamina pada bagian weblebih tinggi dari pada sifat balok dengan profil rekatan 
vertikal. Sifat kekuatan balok silang-I laminasi dengan profil rekatan vertikal ataupun horisontal tersebut lebih rendah dari pada sifat balok kayu karet utuh bebas cacat, tetapi untuk balok silang-I laminasi dengan profil rekatan horisontal lebih tinggi dari pada produk balok laminasinya (glulam). Ini berindikasi pembuatan balok silang-I laminasi dari kayu karet tua terutama dengan profil rekatan horisontal pada bagian web lebih berprospek karena dapat menghemat pemakaian bahan baku kayu.

\section{DAFTAR PUSTAKA}

Anonim. 1956. Timber Design and Construction Handbook. F.W. Dodge Corporation. New York. 263-327 pp.

. 1957. Forestry Handbook. The Ronald Press Company. New York.

1984. Standard Methods of Testing Small Clear Specimens of Timber. American Standard for Testing Material (ASTM) D245. Philadelphia, Pensylvania.

. 1995. Engineered wood products: Thw future is bright. Forest Products Journal, 45 (7/8): 17-24.

. 1999. Wood handbook. Wood as engineering material Agricultural Handbook No. 72. Forest Products Laboratory, USDA Forest Service. Madison, Wisconsin. 10-1 -10-11 pp. Jakarta

2002. Statistik Kehutanan Indonesia tahun 2001-2002. Departemen Kehutanan.

2003. The Development of Small-Diameter Logs and Non-Wood Forest Products Processing Industry. Foresttry Research and Development Agency. Brief Report. Jakarta, Indonesia. Jakarta

2005. Statistik Kehutanan Indonesia tahun 2004-2005. Departemen Kehutanan.

2006. Kayu Alam Distop Total: Laju Degradasi Hutan Mencapai 2,87 hektar per tahun. Harian Kompas, tanggal 28 April 2006, Hlm. 22, Jakarta

Beer, F.P. dan E.R. 1987. Johnston. Mechanics for Enggineers: Statics, fourth edition. McGraw-Hill Book. Co. New York.

Blomquist, F.F., A.W. Christiansen, R.H. Gilepsie, and G.E. Myers. 1981. Adhesive Bonding of Wood and Other Structural Materials. Forest Products Laboratory, Forest Service, USDA. The Pennsylvania State Univ. PA. 16802, USA.

Brown, H.P., A.J. Panshin, dan C.G. Forsaith. 1952. Textbook of Wood Technology, vol. II. McGraw-Hill Book Co. New York.

Floyd, S.L. dan N.P. Kutscha. 2000. Development of Softwood Plantation Timber in The United States. Forest Products Journal, 50 (11/12): 20-24 
Freas, A.D. dan M.L. Selbo. 1954. Fabrication and Design of Glued Laminated Wood Structural Members. Technical Bull. No. 1069. USDA Forest Service, Forest Products Laboratory. Washington, D.C.

Haygreen, J.G. dan J.L. Bowyer. 1989. Forest Products and Wood Science. Lowa State University Press / Ames. 213-226 pp.

Hunt, J.F. 2000. Utilization of Small-Diameter Crooked Timbers for Use in Laminated Structural Boards Through Development of New Sawing, Laminating, and Drying Processes. Proposal No. 01.FPL.C2 to USDA Forest Service, Forest Products Laboratory. Madison, Wisconsin.

Hunt, J.F. and J.E. Winandy. 2003. Lam I-joist. A New Structural Building Product From Small-Diameter, Fire-Prone Timber. Research Note FPL-RN-0291. Forest Products Laboratory, USDA Forest Service. Madison, Wisconsin. 1-4 pp.

Leichti, R.J. 1986. Assessing The Reliability of Wood Composite I-Beam. Ph.D. Dissertation. Auburn University (Limited Circulation).

Maloney, T.M. 1986. Juvenile wood. Problems in Composition Products. In: Proc. 47309 Juvenile Wood. What does it Mean to Forest Management and Forest Products. Forest Products Research Society. Madison, Wisconsin.

Martawijaya, A., I. Kartasujana, K. Kadir, S.A. Prawira, dan Y.I. Mandang. 2005. Atlas kayu Indonesia. Jidid I, II, dan III. Departemen Kehutanan, Badan Litbang Kehutanan. Bogor, Indonesia.

Martono, D. 2006. Potensi kayu karet jangan dilupakan. Ranting Warta Hasil Hutan, 1 (1): 23. Pusat Litbang Hasil Hutan. Bogor.

McGavin, R.L., M.P. Davies, dan W.J. Atyeo. 2006. Utilisation Potential and Market Opportunities for Plantation Hardwood Thinnings from Queensland and Northern New South Wales: Manufacturing and Products. Project No. PN05.2022. September 2006. Forest and Wood Products Research and Development Corporation. Australian Government.

Nurhayati, T., Y. Waridi, and H. Roliadi. 2006. Progress in The Technology of Energy Conversion from Woody Biomass in Indonesia. For. Stud. China, 8 (3): 1-8.

Oey Djoen Seng, 1990. Berat Jenis dari Jenis-Jenis Kayu Indonesia dan Pengertian Beratnya Kayu Untuk Keperluan Praktek. Pengumuman No. 13. Pusat Penelitian dan Pengembangan Hasil Hutan, Badan Litbang Kehutanan, Departemen Kehutanan. Bogor.

Panshin, A.J. and de Zeeuw. 1980. Textbook of Wood Technology. McGraw-Hill Book Co. New York. 288-308 pp.

Selbo, M.L. 1975. Adhesive Bonding of Wood. Technical Bulletin No. 1512. USDA Forest Service, Forest Products Laboratory. Washington, D.C.

Silva, S.S. 1970. Industrial Utilization of Rubber Wood for Wood-Based Panel Products. R.R.I.C. Bulletion (New Series). September/December 1970, vol. 5 (3/4): 40-57. The Rubber Research Institute of Ceylon. 
Rachman, O. 1999. Sawing Technology, Part I: Wood Material and Sawing Process. Center for Forest Products Research and Development. Bogor, Indonesia. (Unpublisdhed)

Walker, J.C.F., B.G. Butterfield, J.M. Harris, and J.M. Uprichard. 1993. Primary Wood Processing. Chapman \& Hall. London. 321-374 pp.

Youngs, R. dan A.L. Hammet. 2001. Diversity, Productivity, Profitability, Sustainability, and The Tao of Underutilized Species. Forest Products Journal, 51 (1):29-35.

\section{UCAPAN TERIMA KASIH}

Dengan tersusunnya tulisan, penulis mengucapkan terima kasih dan menyampaikan rasa penghargaan setinggi-tingginya pada Prof. Dr. Ir. Osly Rachman, MS, sebagai Peneliti Utama pada Pusat Litbang Hasil Hutan (Bogor) yang telah banyak menyumbangkan tenaga dan pikirannya dalam kegiatan penelitian terkait dengan tulisan ini. 